\title{
An Analysis On Takaful Operation Under Conventional Regulator: A Sri Lankan Experience
}

\author{
${ }^{\text {aS }}$ Seyed Mohamed Mohamed Mazahir \\ ${ }^{\mathrm{b}}$ Asmak Ab Rahman \\ ${ }^{c}$ Mohammad Ismath Ramzy

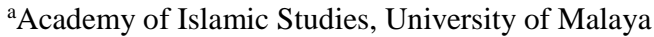 \\ bDepartment of Shariah and Economics, Academy of Islamic Studies, \\ University of Malaya \\ cDepartment of Educational Foundations and Humanities, Faculty of \\ Education, University of Malaya
}

Abstract

In this contemporary world, insurance plays a significant role in the affairs of a human being. It has become inevitable in the life of people. This study aimed at analysing the operations of Takâful (Islamic insurance) companies that are regulated by the Civil Law and finding their core regulatory issues in Sri Lanka. This study highlights the role of Sharī'ah Advisory Council in Takäful industry in Sri Lanka as this council formulates policies and guidelines, and ensures the investment and operation in line with Shari 'ah principles. The research also discusses core issues relating to Islamic insurance such as operation, investment, reporting and separation of funds. It argues that there is a need for the Muslim Leaders as well as the Sharī'ah scholars, Takāful operators and academics to be effectively involved in designing a framework for Takâful regulations in Sri Lanka. Finally, the research recommends the establishment of a regulatory council that will be responsible for the formulation of Takaful Law in that will be similar to that of the Malaysian Islamic Financial Service Act 2013 (IFSA), in Sri Lanka. 
Keywords: Takāful Regulator, Conventional Regulator, Takāful Operations, Issues in Takāful practices in Sri Lanka

\section{Introduction}

Insurance business in Sri Lanka commenced with the advent of coffee and tea industry during the period of British rule. The insurance industry at that time comprised well known foreign companies such as Sun Life Insurance Co., Royal Assurance Co., New India Assurance Co., which were with Edward Lumley underwriting business for Lloyds of London. Thus, after passing the Companies Act of 1938, the first Sri Lankan insurance company the "Ceylon Insurance Company Ltd" was established (Jeya Thangakone, 2001). However, these private insurance companies were nationalised in line with the prevailing national economic policy of the government in 1961. As a result, the Sri Lanka Insurance Corporation was set up as the sole authorised insurance company in the country.

In 1986, the amendment of the Control of Insurance Act No. 25 of 1962 opened the doors for the private sector once again to venture into the business of insurance. In 2000, the Regulation of Insurance Industrial Act (RIIA) no. 43 of the year 2000 was enacted by Sri Lankan Parliament to provide authority to establish an Insurance Board with the purpose of improving, monitoring, developing, supervising, and regulating the insurance industrial sector. RIIA states "under this Act, the Insurance Board of Sri Lanka which is responsible for the supervision, development, and regulation of the insurance industry in Sri Lanka." (RIIA No. 43 of 2000, no. 1 and 2, p. 1).

In 2016, 30 insurance companies, 57 insurance brokers and 45,433 insurance agents were authorised to transact insurance business in Sri Lanka. This operation includes international players like Allianz and AIA Insurance Co. (Insurance Board of Sri Lanka (IBSL), 2015, 
pp. $23 \& 24)$. The statistics reveal that the total assets of the gross written premium of Sri Lankan insurance industry and the gross domestic product (GDP) of the country have witnessed a notable growth in recent past ${ }^{1}$.

RAM Ratings Lanka, a domestic agency for credit rating, functioning under the registration of the Sri Lankan Securities \& Exchange Commission, envisages the industry to maintain this positive trend which is supported by economic growth. It is notable that greater penetration is in northeastern regions of the island. It is observed that there are several new players arrived in the industry recently. Simultaneously, the established players have shifted their mode of operation from price-based to quality service (RAM, 2011, p. 2). It means the competitors in the competitive market of Insurance supply their products of insurance not based on the prices of the product in the market, but they compete the competitors in the market with their products based on the quality of services rendered by them in consideration of supplying this sort of service.

With the industry balanced for growth, IBSL implemented a newly formatted regulatory framework. Primarily, the existing General and Life Insurance business was divided into the separate legal entities. (IBSL, 2015, p. 7). Listing on the domestic stock exchange is also made mandatory. And also, the contemporary and new players are given 3 and 5 years respectively to fulfil.

However, the introduction of Takâful- Islamic insurance system into the country is fairly recent. It only started in 1999 as a result of the emergence of the Islamic Haläl products in Sri Lankan and as an alternative to the conventional insurance practices. It commences with the establishment of Amana Takāful Ltd in 1999. Thus, the high demand for the Islamic financial products prompted the conventional operators also to be involved in the practices of

\footnotetext{
${ }^{1}$ For more details see: IBSL, 2015, pp. 4 and 11
} 
Islamic insurance. Instances of the conventional insurance institutions that involve in the Islamic insurance practices are Ceylinco consolidated which has more than 500 subsidiaries. It established a new subsidiary for the practice of Islamic insurance in 2006 and named it Ceylinco Takäful Ltd. ${ }^{2}$ In addition, Hatton National Bank (HNB) which is a conventional bank, also establishes a window operation in July 2013 and it was named HNB Takāful Assurance.

\section{Regulatory Supervision for Sri Lankan Insurance industry}

In ensuring the smooth functions of the insurance business, the government has a system to monitor the insurance operations using reliability and in a proficient way through a perspective of safeguarding the interests of participants and potential policyholders. For this reason, the government intervenes in the insurance business in three basic methods namely (1) legislation, (2) administrative action, and (3) legal action. The legislation is the foundation of insurance regulations, and the government creates insurance law. The insurance laws of each state are often combined in a code of insurance. The application and enforcement of insurance laws are handed over in the hands of the insurance authorities while the legal action delivers necessary interpretations to the troublesome sections of the law (Bickelhaupt, 1983, pp. 860 \&861).

Hence, after the enactment of the law by the legislative council, the government administered the insurance operations through statutory insurance regulatory body to enforce the law (Mayhall, 2011). The regulatory body is responsible for the issuing licence, and the preserving of the financial solvency of insurance players.

${ }^{2}$ Ceylinco Takâful PLC has been suspended by Insurance Board of Sri Lanka in 2009 until further notice due to improper financial and accounting activities. 
This body is responsible for the standardisation of insurance policies and products, as well as the controlling of the market conducts and the preventing unfair trade practices in the insurance industry (Klein, 2008).

According to Khorshid (2004), one of the main purposes for the State Control of the insurance industry is to ensure that the insurers carry out their obligations toward their customers. This practice is to prevent the possibility of evading the required legal obligations or the complication and the invalidation of the process of claims and avoidance of payments (Khorshid, 2004). Therefore, the government's supervision of the regulatory body is important to ensure the legal compliance of the insurance services and for the protection of the right of the policyholders.

The regulatory mechanism of insurance is different from one country to another. Some countries, national authority regulates insurance operations while some other countries state governments only regulate the operation without the concern of federal government. According to North American Insurance Leaders 10-K 2007 Report, the insurance operation in the United States is regulated by the state regulatory body known as typically Division of Insurance, Department of Insurance, Insurance Bureau or something similar. However, this body has membership in the National Association of Insurance Commissioners or the NAIC. (Wikinvest, 2007).

In the case of Sri Lanka, the 'Insurance Board of Sri Lanka (IBSL)' is the apex body to regulate and monitor the insurance business under the direction and supervision of the Central Bank of Sri Lanka (CBSL). The Central Bank of Sri Lanka (CBSL) which was established in the year 1950 under the 'Monetary Law Act No. 58 of 1949 (MLA)', as the apex institution in the financial sector of Sri Lanka and authority for the entire financial activities in the country, supervise the activities of the IBSL. Hence, under the supervision of Deputy Governor in charge of the financial stability 
representing CBSL which is as a member of the IBSL monitors and observes the activities of IBSL. On the other hand, Central Bank of Sri Lanka is not provided with the powers to control the business of insurance without the approval of IBSL. Therefore, IBSL is an authorised body to control and monitor the operational activities of Sri Lankan insurance industry.

The IBSL operates the regulative and supervising part of the insurance industry including companies, their agents and the brokers, under the 'Regulation of Insurance Industrial Act No. 43 of the year 2000'. Before circulation of the Act, the insurance industry was standardised by the Director of Insurance operating under the authority conferred by the 'Direction of Insurance Act, no. 25 of 1962'. Then, this Act was abolished by introducing the new Act in the year 2000 (IBSL, 2011, p. 16). The IBSL has been established under the Act with the intention of improving, monitoring, directing and regulating the insurance business. This establishment also ensures that insurance business in the country is implemented with reliability, proficiently and practically, with a perspective of preserving the interests of policyholders and prospective policyholders (IBSL, 2011, p. 16).

Since then, a number of several amendments have been incorporated into the foremost ratification of the Act, and supplementary legislation made to reinforce the insurance industry (IBSL, 2011, p. 16). Thirty insurance companies were operating as insurers as at the end of the year 2015. The postponement of registration imposed on Ceylinco Takâful Limited goes on from 2009. Out of the thirty companies, 3 companies were combined insurers, offering both general and long-term insurance business, 12 companies were in operation of the long-term insurance, and 15 companies were in operation of the general insurance business (IBSL, 2015, p. 23). In respect of Division 80 in this Act, a business that has interest in engaging a brokering 
insurance institution in the country has to integrate an institution under the 'Companies Act, No. 7 of 2007'. It also has to register as a broker of insurance under this Act after being satisfied all the legal requirements under the Act. As at the end of 2015, 57 companies were engaging at the brokering service in the country. Of the above-specified companies, 39 companies were registered in general and long-term insurance brokering when 18 companies were registered in the brokering of general insurance (IBSL, 2015, p. 24).

According to section 34 of this Act, the agents of insurance are one of the major instrumental ways of distribution by which the insurance players get hold of the insurance business. The overall number of insurance agents which represent the insurance players on $31^{\text {st }}$ of December, 2015 was approximately 45,433, which is $5.76 \%$ of the increase from the previous year approximately 42,958 (IBSL, 2015, p. 24).

\section{Challenges face by Takäful Industry due to IBSL Regulatory Supervision}

As stated earlier, the system of Takâful insurance in Sri Lanka commenced its operational activities separately from the system of conventional insurance, and it is being regulated by the IBSL - the board which also regulates the conventional insurance system in Sri Lanka. Therefore, IBSL originates the regulatory criteria for Islamic insurance institutions with the similar criteria to conventional insurance companies of Sri Lanka (IBSL, 2015, p. 22) even though Amana Takâful, commenced its operational activities under the special category without the supervision and direction of insurance regulatory body (IBSL).

The IBSL annual report (2001, P. 6) reveals, "Amana Takāful PLC is recognized as non-conventional insurance company applying both the general insurance business and 
long-term insurance business and as per the way of Islamic principles, and is not regulated by the Controller of Insurance business because it is excepted through the Ministry of Finance under the authority and power being vested in the Minister by the Control of Insurance Act No. 25 of 1962. As the Regulation of Insurance Industrial business Act No. 43 of 2000 does not grant any power or authority on the Minister of Finance to free any insurance company from the provisions of the Act and as there were no intermediary provisions sanctioning the continuation of this company as a licensed insurer, the Board requested Amana Takâful PLC (Public Limited Company) to get the registration after having fulfilled all these terms and conditions required under this Act." Amana Takāful PLC submitted their application for the process of registration with an earnest request of allowing the company to invest in Bullion Exchange which is one of the largest and longest standing jeweller manufacturers in Sri Lanka.

IBSL decided to take steps to revise Section 25 of the Act which is dealing with the long-term insurance finance and procedural reserves of general insurance business in terms of their investments to accommodate the request made by Amana Takāful PLC. Even though IBSL made changes according to the request of Amana Takâful PLC and registered it under the Act in February, 2002 (IBSL, 2003, p. 6), there is no phrase or indication to Sharī 'ah supervision notified in any part of IBSL's documents up till now (IBSL, 2011, p. 41).

In addition, the system of Takâful in Sri Lanka is trapped with facing challenges from Takāful regulations. As stated earlier, there is no separate regulatory establishment for Takâful insurance in the country. Presently the IBSL under the terms and conditions of this regulation of 'Insurance Industrial Business Act, No. 43 of 2000, deals with Takâful in the manner with the similarity to the system of conventional insurance regulatory by using the general 
regulations and monitory policies. Hence, the Takâful insurance industry in Sri Lanka faces hardships to operate the Islamic insurance in terms of Islamic Sharī'ah. These challenges can be summarized as operations of Takâful, investment, reporting and separation of funds, management of surplus or deficit and retakâful arrangements.

\section{Takāful Operations}

Takâful operations are directed through the selection of model and the contract between the Takaful operators and the policyholders. As per the Islamic governing principles, these operations should be clear, vivid and without interest $(R i b \bar{a})$ in investment, operations, uncertainty (Gharar) and gambling (Mysir). Hence operationally, to make sure the appropriate regulations of Takâful, the regulators must have an appropriate infrastructure which allows them to monitor the operations of Takâful in an obvious and exact method while holding to the beginning doctrines of aforementioned Islamic notion. Such improved regulation requires a practical understanding of these operations to raise the fears that "Takâful operators are just Sharī'ah compliant on paper". (Abbas Mohamed, 2012, p. 2). Even though Sri Lankan Takäful industry has adopted these principles in their concepts, the question remains on the level of pursuing the Sharī'ah Principles in operations.

\section{Investment of Funds}

Takāful insurance operators can only invest in Sharī'ah compliant instruments. The regulators have to make sure the compliance of Shari'ah by adopting the frameworks that are developed by the authoritative bodies like 'Accounting and Auditing Organization for Islamic Financial Institutions (AAOIFI)' or the 'Islamic Financial 
Service Board (IFSB)' or other institutions. On this matter, there is no Islamic investment regulation or framework included in Insurance Act of Sri Lanka or the circulars being circulated by IBSL. Although the Shari'ah Advisory Council does this job in Sri Lanka with the support of some organisation such as IGL Lanka Limited, Amana Global Ltd, two subsidiary companies of Amana Takāful PLC, this Sharīah Advisory Council does not have enough authoritative legal provisions to take complete decisions on investment.

According to a member of Shari'ah Advisory Council, Amana Takâful PLC invests the contributions that are collected from the participants in five major avenues such as equity or the stock market, treasury bills, fixed deposits in Islamic banks products and real estates, and bullion exchange. In Treasury Bills, according to the governing Act of 2000, Amana Takāful need to invest not less than $20 \%$ of the assets of the technical reserve ${ }^{3}$ and to maintain not less than $30 \%$ of the assets, under section 24 for the fund maintained by Long-Term Insurance should be in the type of Government Securities. The balanced properties should be in the type of other investments as should be suggested by this Board (Regulation of Insurance Industry Act No. 43 of 2000, Part II - Registration of Insurers, section $25(1))$. It is a compulsory requirement for all the insurance companies.

\footnotetext{
3“'Technical reserve' include net unearned premium, provision made for unexpired risks, net claims outstanding, reserve for claims incurred but not reported (IBNR) and any contingency reserves, less any deferred acquisition expenses; and "unexpired risks" means the amount set aside at the end of a financial year of an insurer, (in addition to net unearned premium) in respect of risks to be borne by such insurer after the end of such financial year under a contract of insurance entered into prior to the end of that financial year." (Regulations of Insurance Industry Act No. 43 of 2000, p.5).
} 
Although Amana Takāful PLC is allowed to invest in equity (stock market) that are approved by Sharī'ah board or to invest in bullion exchange with Shari 'ah guidelines, or to invest in fixed deposits in Islamic fully fledged banks or to invest in real estates, the compulsory investment in Treasury Bills has become an issue as it is an interest-based instrument. Investment in Treasury Bills brings two issues; it affects the revenue of the operator because interest income cannot be recognised, and it also poses a reputational or an image-risk to the operator with public perception as it indulges in non-Islamic transactions.

\section{Reporting and Separation of Funds}

Reporting and separation of finance refer to making sure the shareholders and risk fund resources. Both of these funds should not be mixed in Takâful operational activities. The segregation of these funds makes sure the ownership and transparency together. In addition, the investment income, surplus/deficit, the segregation of funds, and Wakālah fees make easy to analyse properly. Thus, without the appropriate separation of funds, the perception of Takâful insurance is similar to conventional standard, and the whole programme is conciliated.

The segregation of fund depends on the features of the intentions of the investments and investment tools. Accounting procedures reveal that Islamic financial organisations should carry out this separation. Likewise, the new accounting direction entry on First Time Adoption of AAOIFI Accounting Standards leads to Islamic financial institutions with the initial point for the preparation of financial accounting entries and records by AAOIFI standards. In Malaysia, under IFSA 2013, section 91 endorsed that the fund of shareholders and the Takâful fund should be separated. It is because that each fund belongs to 
a different party and it should be treated differently as per the ownership. Thus, the segregation of shareholder and participatory funds, guaranteeing appropriate accounting and reporting of these funds in a different manner present a clear framework for Takäful operation (Abbas Mohamed, 2012, p. 2).

Sri Lankan Takāful insurance industry is following the conventional methods in reporting to IBSL. It is because of a void of Takâful Act in Sri Lanka.

\section{Treatment of Surplus/Deficit}

Insurance surplus is considered one of the main pillars and prominent characteristics of Takäful companies. Aspects of ambiguity and gamble are eradicated from the Takāful procedure, and absolute equity and mutual cohesion are attained by surplus declaration (Sabbagh, 2010, p.1). The framework of distribution is also prudently standardised at supervisory level because it has an additional capability to either lean the playing field in favour of Takäful or just perform as a void promise. Indeed, there should be a clear regulatory guideline to manage this issue. Otherwise, every Takâful company or window takes the decisions on their perception. This outcome is merely the results of the absence of Takāful regulatory system.

Sri Lankan Takâful industry faced only deficit up to 2014. This industry managed the deficit with the fund of the shareholders.

\section{Retakāful Arrangements}

Retakāful is an arrangement or a mechanism either by an agreement covering a class of Takäful product or a risk by risk basis that enables a direct Takâful operator, called the 'cedant', to transfer or cede the whole or a part of the risk 
that it has accepted, to another Takâful or retakäful operator (Mohd Fadzli, Wan Zamri \& Abdul Khudus, 2011, p. 517).

Retakāful, as well as Takāful, should be Sharī'ah compliant as indicated in the resolution of the Fiqh Academy (Resolution No: 9, December 1985), “...commercial insurance contract commonly used by commercial insurance companies is a contract which contains major elements of risks which is prohibited according to Sharī'ah. The alternative for both insurance and reinsurance should be based on the principles of corporative insurance..." (Majma' al Fiqh al Islami al Duwali, Resolution No: 9 (9/2), 1985). In this connection, Yassin and Ramly (2011) point out that "Sharī'ah principles applicable to Takâful should be applied to Retakāful as well. In principle, Retākaful is not different from Takäful procedures; this main difference is that in the Retakaful operational procedures, the participatory shareholders are known as Takâful operators other than individual participants." (Yassin \& Ramly, 2011, p. 250).

Based on the above quotations, Sri Lankan Takäful insurance industry also should look for Retakāful insurance companies which operate by the Sharī'ah principles. In practice, all the reinsurance companies are not recognised as Sharī'ah compliant. For instance, Amana Takäful PLC is listed as its reinsurance companies. According to that its reinsurers are BEST $\mathrm{Re}^{4}$, Hannover Re, Labuan Re, Tokio

\footnotetext{
${ }^{4}$ BEST RE (L) was established in April 1985 as an Off-shore reinsurance company with headquarters based in Tunis (Tunisia), where it operates under Law No 85-108 dated 6th Dec. 1985. Under this law, BEST RE (L) enjoys the benefit of a tax-free environment and is regulated by the Tunisian Insurance Code, which is largely similar to the French insurance legislation. BEST RE (L) operates in compliance with Islamic principles (Art. 3 of its bylaws) and as such is considered as the world's Retakaful pioneer. BEST RE (L) is fully owned by SALAMA Group (Dubai - UAE), which comprises 7 other direct Takaful companies. Since inception, BEST RE (L) has focused on developing a profitable reinsurance portfolio in the emerging markets of Africa and Asia. It currently covers more than 90 countries in this region through a network
} 
Marine, Catlin, Malaysian Re, Trust International, ACR Retakāful and MNRB (Amana Takāful PLC, 2012, pp. 137 $\&$ 138). Hence, Takāful insurance system in Sri Lanka uses non-Sharī'ah based Retakäful. Therefore, there are nonIslamic elements in Sri Lankan Takâful system. This gap necessities Sharī'ah based Retakäful system to ensure Islamic practices.

\section{Approaches to Regulate Takäful Industry}

To make sure smooth function and growth, two different approaches have been used to regulate Takâful operations. When some of the nations have enacted a unique Takāful law, other nations have customised their present regulatory frameworks and rectified them to the particular requirements of Islamic insurance. In countries where Takāful grows speedily, regulators have to recognize, improve, and distribute risk-management best performance taking into the consideration of the contractual associationship of Islamic insurance productions (Vayanos, 2012, p. 14) and the regulators requires to make sure the accessibility of training programmes so as make aware of the market on such comparatively new productions (Vayanos, 2012, p. 12). However, in the countries where Takāful does not grow rapidly, the existing regulatory frameworks were subject to amendments within the purview of the law of the country and the social environment.

Even though the development of Takâful insurance companies in Sri Lanka is comparatively good, it is monitored and regulated by IBSL. Unfortunately, IBSL does not improve, recognise, and distribute the best practices of risk-management that are subject to taking into consideration of the contractual association-ship of Islamic

\footnotetext{
of four regional offices in Labuan (Malaysia), Beirut (Lebanon), Istanbul (Turkey), Dakar (Senegal) and 3 contact offices in Beijing (China), Manila (Philippines) and Port Louis (Mauritius).
} 
insurance productions. Therefore, Takāful insurance system needs a modified system or a separate regulatory system in Sri Lanka with the accommodation of Sharī 'ah provisions.

\section{Recommendation}

In this context, it seems that the authorities of government or relevant persons connected with Takâful insurance industrial sector did not consider the necessary initiatives in Sri Lanka to generate a unique regulatory system that is appropriate to Sri Lankan context. Even though IBSL did agree to accept the investment in Bullion, it does not imply that IBSL permits investment and any other activities with the compliance of Sharī'ah.

Even though the Takäful insurance system is operated separately from conventional insurance system in Sri Lanka, it is monitored and regulated by the IBSL - the board which also monitors and regulates the system of conventional insurance.

IBSL devises the regulatory principles designed for the Islamic insurance institutions which are similar to the companies of conventional insurance (IBSL, 2015, p. 22). Thus, from the viewpoint of the government regulatory board, no components are found to differentiate conventional insurance from Takâful insurance system in Sri Lanka.

IBSL agrees to allow Takāful insurance companies and Takâful windows to adopt Sharī 'ah advisory council to supervise and monitor the investments and transactions according to the Sharī'ah principles. Therefore, Takâful insurance companies might have practised a Sharīah advisory council for each of the insurance company, but, no any of initiative is taken to employ a committee of Shari' 'ah advisory as per the guidelines which are approved by the state regulators. 
Hence, this main difference between the Takäful insurance and the conventional insurance is adopting inhouse Islamic regulatory committee which is recognised as Sharí 'ah Advisory Council (SAC) in each Takäful insurance company. This council deliberately audits the products of Takāful insurance and services of Takāful insurance to make sure its compatibility is in line with the principles of Islamic perspectives. It is recommended that the Sharī ah scholars, Muslim political leaders, academicians, and Takāful operators should take initiatives to generate a regulatory framework designed independently for Takäful insurance system in Sri Lanka by introducing a separate and a unique Takäful Act or a complementary for Takäful insurance in addition to the existing Insurance Act. It is also recommended that in revising the separate Takäful Insurance Act or a complementary for Takäful insurance for the context of Sri Lanka, the Islamic Financial Service Act 2013 (IFSA) being currently practiced in Malaysia could be adopted because the Malaysian model in this connection is practicable and deals with the many issues of Sri Lankan Takâful insurance industrial sector.

\section{Conclusion}

Insurance is closely connected with the life of people today. The operational activities of Takäful insurance under traditional regulatory system need a multi-dimensional analysis. In ensuring the smooth function and operation of Takäful insurance, Sharī'ah Advisory Council plays a major role. This council designs and provides guidelines and criteria for the supervision, operation, and monitoring.

The question in this study is how deep Takâful insurance practices in Sri Lanka deals with the core issues found in the investment of funds, operation, reporting and separation of funds, Retakäful arrangements, and treatment of surplus/deficit by Sharī 'ah principles. 
Hence, it is recommended to institute a separate government regulatory council for Takāful insurance industry in Sri Lanka while highlighting issues in Takâful operation and regulatory supervision. It is recommended the Malaysian model in adopting a separate TakäfulAct or a complimentary for Takāful.

\section{References}

Abbas Mohamed, (2012). Takāful Regulation in a Conventional set-up, Takāful Articles, No: 24, ICMIF Takāful.

Aly Khorshid, (2004). Islamic Insurance - A Modern Approach to Islamic Banking, London, UK: Routledge Curzon,

Amana Takāful PLC, Annual Report 2012.

Central Bank of Sri Lanka, About the Bank, retrieved from http://www.cbsl.gov.lk/htm/english/03_about/a_1.htm laccessed on 3 June 2013.http://www.infoplease.com/country/srilanka.html on 8th October 2013.

David, L. Bickelhaupt, (1983). General Insurance, $11^{\text {th }}$ Edition, Illionois (USA): Richard D. Irwin, INC.

Department of Census and Statistics Sri Lanka (2012),

Population by Religion according to District,

Department of Census and Statistics Sri Lanka.

Insurance Board of Sri Lanka (IBSL, 2001), Annual Report 2001. Colombo: Insurance Board of Sri Lanka Insurance Board of Sri Lanka (IBSL, 2005), Annual Report 2005. Colombo: Insurance Board of Sri Lanka Insurance Board of Sri Lanka (IBSL, 2006), Annual Report 2006. Colombo: Insurance Board of Sri Lanka Insurance Board of Sri Lanka (IBSL, 2011), Annual Report 2011. Colombo: Insurance Board of Sri Lanka Insurance Board of Sri Lanka (IBSL, 2012), Annual Report 2012. Colombo: Insurance Board of Sri Lanka 
Insurance Board of Sri Lanka (IBSL, 2014), Annual Report 2014 Colombo: Insurance Board of Sri Lanka Insurance Board of Sri Lanka (IBSL, 2015), Annual Report 2015 Colombo: Insurance Board of Sri Lanka Jaffer, S., (Ed.), (2007). Islamic Insurance: Trends, Opportunities and the Future of Takäful, London (UK): Euromoney Institutional Investor PLC.

Jeya Thangakone. (2001). Insurance Industry \& General Insurance in Sri Lanka. The Sri Lanka Insurance Institute.

Klein, Robert W. (2008). An Overview of the Insurance Industry and Its Regulation, Center for Risk Management \& Insurance Regulation, Georgia State University.

Lim, J., Idris, M.F., \& Carissa, Y. (2010). History, Progress and Future Challenge of Islamic Insurance (Takäful) In Malaysia, 2010 Oxford Business \& Economics Conference Program ISBN : 978-0-9742114-1-9

Majma' al Fiqh al Islami al Duwali, Resolution No: 9 (9/2) on Insurance and Reinsurance, Jeddah, KSA, December 1985.

Mayhall, Van, III, Insurance Regulatory Law: Defined, Insurance Regulatory Law. Retrieved 201106-02

Mohd Fadzli, Y., Wan Zamri, W.I., \& Abdul Khudus M.N. (2011). Fundamentals of Takāful, Kuala Lumpur, Malaysia: IBFIM.

Mortuza Ali, K.M. (2013). Challenges of Takāful and Required Regulatory Framework, The Financial Express, April 20, 2013, Dhaka.

RAM, (2011). Insurance Sector Update - Bright Prospects despite Regulatory Changes, pp. 2 and 3, Colombo: RAM Ratings Lanka, retrieved on $2^{\text {nd }}$ June 2013 through

http://www.ram.com.lk/other_pdf/Insurance-SectorUpdate-11.pdf 
Regulation of Insurance Industry Act No. 43 of 2000. Sabbagh, A.M. (2010). Insurance Surplus in Islamic Insurance Companies, Takāful Articles, No.22

Securities and Exchange Commission of Pakistan (SECP), Takäful Rules 2012, Part V Compliance with Principles of Sharī'ah.

The Gazette of Democratic Socialist Republic of Sri Lanka, No. 1414/19, October 12, 2005, Government Notifications, Regulation of Insurance Industry Act, No. 43 of 2000.

The Global Takāful Insights, (2014). Ernst \& Young.

The World Takâful Report 2011, (April 2011). Ernst \& Young, Dubai, UAE: MEGA

Vayanos, P., (booz \& co.) Promoting the Growth and Competitiveness of the Insurance Sector in the Arab World, retrieved on 20 December 2012 through http://www.booz.com/media/uploads/Insurance_Sec tor_Arab_world.pdf

Website of Ernst \& Young, retrieved through http://www.ey.com/EM/en/Newsroom/Newsreleases on 28th December 2015

Wikinvest (2007). North American Insurance Leaders 10-K $2007 . \quad$ Retrieved from: http://www.wikinvest.com/stock/North_American_I nsurance_Leaders_(NAO)/Filing/10K/2007/F5356727.

Yassin, N., \& Jamil R. (2011). Takāful: A Study Guide, Kuala Lumpur, Malaysia: IBFIM. 